Tersedia online di: http://ejournal-balitbang.kkp.go.id/index.php/ma

\title{
PENGARUH PENGAYAAN Artemia sp. DENGAN SUMBER DHA YANG BERBEDA TERHADAP SINTASAN LARVA LOBSTER PASIR (Panulirus homarus)
}

\author{
Zeny Widiastuti”, Fahruddin, dan I Gusti Ngurah Permana \\ Balai Besar Riset Budidaya Laut dan Penyuluhan Perikanan \\ JI. Singaraja - Gilimanuk, Banjar Dinas Gondol, Penyabangan, Gerokgak Kabupaten Buleleng, Bali 81155
}

(Naskah diterima: 5 April 2021; Revisi final: 10 Juni 2021; Disetujui publikasi: 10 Juni 2021)

\begin{abstract}
ABSTRAK
Kegiatan pembenihan lobster masih dikembangkan di Indonesia. Sintasan yang rendah dan pakan yang sesuai masih menjadi masalah utama dalam kegiatan pembenihan lobster. Artemia sebagai pakan utama diduga belum mencukupi kebutuhan nutrisi larva lobster. Upaya pemberian bahan pengaya sebagai alternatif untuk meningkatkan nutrisi diharapkan dapat meningkatkan sintasan larva lobster. Pemberian bahan pengaya yang mengandung asam lemak dokosa heksanoid acid (DHA) ke Artemia dianggap penting bagi pertumbuhan dan sintasan pada krustasea. Tujuan penelitian ini untuk mengetahui performa larva lobster berdasarkan tingkat sintasan maupun perkembangan larva dengan pemberian pakan artemia yang diperkaya dengan DHA. Perlakuan yang diberikan meliputi Artemia yang baru menetas (A), Artemia yang diperkaya dengan plankton Isochrysis galbana strain Tahiti konsentrasi (1-1,5 × $\left.10^{6} \mathrm{sel} / \mathrm{mL}\right)(\mathrm{B})$, DHA selco dosis $0,6 \mathrm{~g} /$ $\mathrm{L}$ (C), dan Artemia inkubasi 18 jam tanpa pengayaan (D). Pemeliharaan larva dilakukan pada bak $100 \mathrm{~L}$ dengan sistem air stagnan. Perkembangan larva yang mampu dicapai pada semua perlakuan adalah stadiaIIla. Pemberian Artemia yang diperkaya dengan DHA selco menunjukkan hasil sintasan yang lebih baik pada pemeliharaan enam hari pertama namun tidak memberikan pengaruh yang signifikan. Pada masa pemeliharaan sampai 20 hari terjadi penurunan sintasan (SR) mencapai hanya $1 \%$ Hal ini disebabkan adanya bakteri dan protozoa seperti jenis protozoa Zoothamnium sp. dan bakteri berfilamen teramati menempel pada tubuh larva sehingga mengganggu pergerakan dan kemampuan larva dalam menangkap mangsa. Berdasarkan penelitian ini maka penggunaan pakan Artemia yang diperkaya DHA Selco dapat menjadi alternatif pakan larva lobster namun tetap diperlukan kontrol kualitas air yang baik.
\end{abstract}

\section{KATA KUNCl: $\quad$ Artemia; DHA selco; Isochrysis; phyllosoma}

ABSTRACT: The effects of different sources of DHA-enriched Artemia sp. on survival rate of spiny lobster, (Panulirus homarus) larvae. By: Zeny Widiastuti, Fahruddin, and I Gusti Ngurah Permana

Efforts to culture spiny lobster, Panulirus homarus larvae are still being developed in Indonesia. One of the main challenges in lobster hatcheries is to find an appropriate feed and improving larval survival. Artemia has been used as the main feed and considered to have insufficient nutritional ingredient for lobster larvae. Enrichment of feed to improve its nutrient contents is expected to increase the larval survival. DHAenriched feed is considered essential for growth and survival of crustaceans. The aim of this study was to determine the survival and development of larvae fed with DHA-enriched Artemia. The treatments consisted of newly hatched Artemia (A), enriched Artemia with phytoplankton, Isochrysis galbana strain Tahiti at a density of 1-1.5 $\times 10^{6}$ cells $/ \mathrm{mL}$ (B), enriched Artemia with DHA selco at a dose of $0.6 \mathrm{~g} / \mathrm{L}$ (C), and Artemia incubated for 18 hours without DHA enrichment (D). Each Artemia enrichment was performed for 18 hours. Larval rearing was carried out in a $00 \mathrm{~L}$ tank with static water system. The achieved larval developmental stage in all treatments was stage-IIla. Administration of enriched Artemia with DHA selco

\footnotetext{
* Korespondensi: Balai Besar Riset Budidaya Laut dan Penyuluhan Perikanan.

Jl. Singaraja - Gilimanuk, Banjar Dinas Gondol, Penyabangan, Gerokgak Kabupaten Buleleng, Bali 81155, Indonesia

E-mail: zeny23ast@gmail.com
} 
Pengaruh pengayaan Artemia sp. dengan sumber DHA ..... (Zeny Widiastuti)

showed a better larval survival during the first six days of larval rearing. But, it did not give any significant effect. The survival was then decreased to only $1 \%$ on day-20. This was due to the presence of bacteria and protozoa which decreased water quality. Protozoa Zoothamnium sp. and filamentous bacteria were observed attaching to the body of the larvae, disrupting the movement and ability of larvae in capturing prey. Based on this research, the use of Artemia enriched with DHA selco as an alternative for lobster larvae feed, but better water quality control is still needed.

\section{KEYWORDS: Artemia; DHA selco; Isochrysis; phyllosoma}

\section{PENDAHULUAN}

Lobster merupakan krustasea yang harganya mahal dibandingkan jenis udang-udangan yang lainnya. Menu lobster jarang ditemukan diwarung makan biasa. Hidangan ini lebih banyak dijumpai di restoran mewah. Permintaan lobster tidak hanya untuk memenuhi pasar dalam negeri namun juga pasar luar negeri dengan nilai yang cukup menjanjikan. Harga jual per kilogram lobster pada size $500 \mathrm{~g}$ untuk lobster mutiara P. ornatus Rp900.000,00; lobster bambu Rp750.000,00; lobster batik Rp800.000,00; dan lobster pasir sebesar Rp700.000,00 (Elvantra, 2021). Besarnya permintaan pasar mengakibatkan tingginya penangkapan lobster di alam dan dikhawatirkan akan menyebabkan penangkapan berlebih (over fishing). Salah satu upaya untuk mencukupi kebutuhan pasar dan mengurangi kegiatan penangkapan adalah dengan melakukan usaha pembudidayaan lobster.

Kegiatan pembudidayaan lobster di Indonesia di mulai pada awal tahun 2000-an di Pulau Lombok. Industri akuakultur di sana mengembangkan teknik sendiri untuk menangkap puerulus atau lebih dikenal benih bening lobster (BBL) dan kemudian menumbuhkannya hingga ukuran yang dapat dipasarkan (Priyambodo et al., 2015; Priyambodo et al., 2020). Selain di Pulau Lombok, budidaya lobster di Indonesia juga sudah dilakukan di Aceh, Nusa Tenggara Timur, dan Sulawesi Selatan (Mustafa, 2013). Namun sampai saat ini kegiatan budidaya lobster masih mengandalkan benih hasil tangkapan alam karena benih hasil dari budidaya belum berhasil dikembangkan. Salah satu kendala dalam pembenihan lobster adalah belum diketahuinya secara pasti jenis pakan dan teknologi pemeliharaan yang sesuai. Selain itu, waktu yang dibutuhkan pada stadia phyllosoma yang merupakan sebutan bagi larva lobster hingga berubah menjadi BBL membutuhkan waktu lama. Stadia planktonik lobster mutiara P. ornatus berkisar 4-6 bulan (Ikeda et al., 2011). Sedangkan stadia larva jenis P. argus membutuhkan waktu 4,5-8 bulan (Goldstein et al., 2008). Durasi stadia larva planktonik yang cukup lama menyebabkan sampai saat ini belum ada usaha pembenihan lobster yang berhasil memenuhi kebutuhan usaha budidaya.
Larva lobster memiliki lima tingkatan stadia. Penanda paling mudah untuk menentukan stadia larva adalah dengan menghitung bulu (setae) pada periopod (kaki renang) ke-1 dan 2. Pada stadia-l, jumlah setae pada periopod ke-1 dan 2 berjumlah lima pasang. Jumlah setae terus bertambah dengan meningkatnya stadia. Jumlahnya berturut-turut adalah sebagai berikut: stadia-II jumlah enam pasang, stadia-IIla sebanyak tujuh pasang, stadia-IIlb sebanyak delapan pasang, stadia-IVa sebanyak sembilan pasang, StadiaIVb sebanyak 10 pasang, stadia-IVc sebanyak 11 pasang, stadia-IVd sebanyak 12 pasang; dan stadia-V sebanyak 13 pasang (Abrunhosa et al., 2008).

Abrunhosa et al. (2008) juga menyebutkan bahwa larva lobster (P. echinatus) yang diberikan pakan Artemia dan gonad kerang mampu melewati fase moulting delapan kali. Di Indonesia, dilaporkan upaya pembenihan lobster pernah dilakukan dengan pemberian kombinasi jenis pakan dari Chaetoceros sp., Tetraselmis sp., dan Artemia salina. Pada pemeliharaan tersebut larva mampu melewati stadiaIlla dengan waktu pemeliharaan 27 hari (Junaidi et al., 2011). Vijayakumaran et al. (2014) juga menggunakan Artemia yang baru menetas sebagai pakan utama dalam pemeliharaan larva lobster. Ketika larva memasuki stadia-III diberikan Artemia yang baru menetas dan Artemia umur 2-3 hari dengan pakan campuran fitoplankton.

Pemberian pakan Artemia saja dalam pemeliharaan jangka panjang mengakibatkan menurunnya sintasan larva dan sulit untuk mencapai perkembangan stadia berikutnya. Spesies Artemia yang tersedia secara komersil memiliki profil nutrisi yang kurang optimal karena memberikan sedikit sumber asam lemak esensial rantai panjang (Matsuda et al., 2009). Karena asam lemak dapat menjadi cadangan energi yang sangat penting dalam keberhasilan perkembangan dan metamorfosis larva lobster (Conland et al., 2014). Artemia dapat diperkaya sebagai salah satu upaya meningkatkan profil nutrisinya sehingga menjadi pakan berkualitas tinggi yang diperlukan dalam perkembangan larva (Matsuda et al., 2009). Oleh karena itu, pada penelitian ini diujicobakan dua jenis bahan pengaya untuk meningkatkan kandungan asam 
lemak pada Artemia yaitu DHA selco dan Isochrysis galbana strain Tahiti. Penggunaan bahan-bahan tersebut didasarkan pada Vijayakumaran et al. (2014) yang menyebutkan beberapa bahan pengaya alternatif yaitu shark liver oil, minyak cumi, cod liver oil, dan media pengaya komersil "super selco (inve, inc Belgium) dapat digunakan untuk memperkaya highly unsaturated fatty acid (HUFA) dari Artemia yang baru menetas. Produk selco tersebut memiliki kandungan DHA sebesar 2,5 $\mathrm{mg} \mathrm{g}^{-1}$ (Prusinska et al., 2020). Selain produk komersil tersebut jenis marine microalga yang banyak digunakan sebagai bahan pengkaya dalam budidaya perikanan adalah jenis Isochrysis gal bana yang kaya akan sumber lemak. Kandungan DHA pada Isochrysis galbana berkisar antara 3,59\%6,37\% bergantung pada $\mathrm{pH}$, mikronutrien, dan vitamin pada media kulturnya (Grima et al., 1992). Tingginya kandungan asam lemak DHA tersebut dapat dijadikan sebagai sumber DHA alternatif yang potensial.

Penelitian ini bertujuan untuk mengetahui performa larva lobster pasir (P. homarus) baik sintasan maupun tingkat perkembangannya dengan pakan yang diperkaya DHA selco dan Isochrysis galbana strain Tahiti dalam kegiatan pembenihan. Selain itu, dengan pemberian bahan pengaya diharapkan nilai nutrisi Artemia menjadi lebih tinggi sehingga mampu mencukupi kebutuhan larva untuk mencapai stadia perkembangan selanjutnya.

\section{BAHAN DAN METODE}

\section{Seleksi Induk Lobster}

Kegiatan penelitian dilakukan pada bulan Mei-Juni 2017. Induk-induk lobster yang digunakan pada penelitian ini merupakan induk lobster hasil budidaya berukuran 150-200 g berjumlah 259 ekor. Induk dipelihara secara massal dengan diberikan pakan berupa ikan rucah dan cumi segar. Pemberian pakan dilakukan setiap hari dengan dosis $5 \%$ dari bobot induk. Induk-induk yang membawa telur diseleksi setiap dua hari sekali dengan memperhatikan warna telur untuk menentukan kesiapan induk mendekati proses penetasan. Telur yang berwarna orange atau kuning menandakan telur masih muda dan telur berwarna kecoklatan atau bening kehitaman menunjukkan telur telah siap untuk menetas. Induk yang mendekati periode penetasan telur dipisahkan dalam bak kerucut satu volume ton.

\section{Penetasan Telur dan Pemanenan Larva}

Induk yang mendekati waktu penetasan dalam bak satu ton diberikan pakan tiga hari sekali. Dosis pakan yang diberikan hanya $1 \%$ pada pagi hari dan pada sore hari induk dipindahkan pada bak berisi air baru. Hal ini bertujuan agar larva yang menetas dalam kondisi bersih dan kualitas air terjaga dari sisa pakan. Seleksi larva dilakukan dengan memisahkan larva yang aktif berenang di permukaan. Sementara larva yang mengendap di dasar bak dibuang. Larva yang digunakan dalam penelitian ini berasal dari satu induk yang sama. Larva yang telah dipanen didesinfeksi dengan iodine $100 \mathrm{mg} / \mathrm{L}$ selama 10 menit. Selanjutnya dilakukan pencucian dengan air laut dan di-sampling sesuai jumlah kepadatan larva yang dibutuhkan di setiap bak perlakuan (50 ekor/liter).

\section{Pengayaan Artemia}

Cyste Artemia yang telah dikultur selama 18 jam dipanen dan didesinfeksi dengan iodine. Selanjutnya ditambahkan bahan pengaya DHA selco (dosis $0,6 \mathrm{~g} /$ $\mathrm{mL}$ ) sesuai saran pada kemasan produk dan Isochrysis galbana strain Tahiti dengan kepadatan 1-1,5 x 106 sel/ $\mathrm{mL}$. Pengayaan dilakukan selama 18 jam kemudian dilakukan pemanenan pada keesokan harinya.

\section{Pemeliharaan Larva}

Larva hasil seleksi dipelihara dalam bak $100 \mathrm{~L}$ dengan sistem air stagnan. Air laut bersalinitas 35 ppt disaring menggunakan membran filter berukuran 0,5 mikron. Volume air pada setiap bak di awal pemeliharaan sebanyak $80 \mathrm{~L}$ dan ditambahkan air dalam jumlah sedikit pada awal pemeliharaan yaitu $10 \mathrm{~L}$ setiap harinya untuk mengurangi stres pada larva dan menurunkan konsentrasi metabolit pada air media. Pada saat mencapai volume $100 \mathrm{~L}$ dilakukan penggantian air sebanyak $20 \%$ hingga akhir pemeliharaan.

Penelitian ini menggunakan tiga perlakuan dengan satu kontrol dan dilakukan pengulangan sebanyak tiga kali pada masing-masing perlakuan. Larva diberikan pakan Artemia dengan masing-masing perlakuan sebagai berikut:

- Perlakuan A: Artemia yang baru menetas tanpa pengayaan (kontrol)

- Perlakuan B: Artemia yang baru menetas diberi bahan pengaya DHA selco

- Perlakuan C: Artemia yang baru menetas diberi bahan pengaya Isochrysis galbana strain Tahiti

- Perlakuan D: Artemia yang diinkubasi selama 18 jam tanpa pengayaan

Jumlah Artemia yang diberikan pada setiap bak diketahui dengan menghitung jumlah larva dan sisa Artemia di dalam bak secara sampling volumetrik. Dosis Artemia yang diberikan adalah dua individu Artemia per satu ekor larva lobster. Dosis pakan meningkat pada hari selanjutnya disesuaikan dengan tingkat konsumsi larva yang meningkat dengan 
bertambahnya umur. Sampling sisa Artemia dilakukan setiap hari untuk mengontrol jumlah Artemia dalam bak. Sintasan larva dihitung dengan melakukan sampling setiap enam hari sekali dan dihitung secara total pada akhir penelitian, sedangkan parameter kualitas air meliputi salinitas dan pH diukur lima hari sekali.

\section{Kultur Bakteri Media Pemeliharaan}

Pengukuran total bakteri dan Vibrio pada air media pemeliharaan dilakukan setiap minggu sekali sebagai kontrol kualitas air media. Kultur bakteri dilakukan dengan mengambil $1 \mathrm{~mL}$ air media dan dikultur pada media marine agar (MA) dengan pengenceran 100x dan tanpa pengenceran pada media TCBS agar. Hal ini bertujuan untuk mengetahui kelimpahan total bakteri dan Vibrio pada media pemeliharaan terhadap pengaruh pengayaan.

\section{Analisis Data}

Data sintasan, total bakteri, dan total Vibrio ditampilkan dalam nilai rata-rata. Analisis data dalam penelitian ini menggunakan uji statistik dengan metode one-way ANOVA karena data yang diperoleh memenuhi asumsi sebaran normal. Pengujian statistik menggunakan program SPSS ver.16 dengan nilai signifikansi $\mathrm{P}<0,05$.

\section{HASIL DAN BAHASAN}

\section{Sintasan Larva}

Pengayaan Artemia dengan menggunakan DHA selco menunjukkan hasil sintasan (SR) lebih baik dari perlakuan lainnya pada enam hari awal pemeliharaan. Nilai SR yang ditunjukkan oleh perlakuan Artemia yang diperkaya selco adalah sebesar $94,6 \%$ dengan jumlah rata-rata larva 4.732 ekor lebih banyak dibandingkan perlakuan lainnya (kontrol $0 \mathrm{H}: 3.044$ ekor, Artemia $18 \mathrm{H}: 4.244$ ekor, Isochrysis : 4.310 ekor) dan terus menurun hingga pemeliharaan 20 hari dengan SR hanya mencapai 1,1\%(Gambar 1$)$ dengan jumlah larva yang mampu bertahan hidup pada perlakuan DHA selco, Isochrysis, dan Artemia kontrol berturut-turut yaitu 54, 53, dan 68 ekor. Analisis data sintasan larva dengan menggunakan uji statistik dengan metode one way ANOVA diperoleh hasil yang tidak berbeda dengan nilai $P$ value $>0,05$.

Salah satu faktor penentu sintasan larva adalah pakan yang sesuai. Pakan sebagai sumber nutrisi berperan penting bagi pertumbuhan dan sintasan larva. Laju akumulasi penyimpanan nutrisi selama stadia awal hingga pertengahan pada larva P. ornatus menjadi komponen vital untuk sintasan dan kesuksesan tahap metamorfosis (Wu et al., 2011; Fitzgibbon et al., 2014). Salah satu komponen nutrisi yang vital adalah lemak. Di alam, akumulasi lemak oleh larva berasal dari mangsa zooplankton (Wang et al., 2015). Pada penelitian ini, analisis kadar lemak dari pakan perlakuan (Tabel 1) diperoleh nilai kadar lemak tertinggi terdapat pada perlakuan pengayaan dengan DHA selco $(21,16 \%$ ) sehingga pengayaan dengan selco lebih berpotensi mampu mencukupi kebutuhan lemak larva lobster. Lemak memainkan peran utama sebagai cadangan energi selama pertumbuhan dan perkembangan larva krustasea. la memanfaatkan sejumlah lemak sebagai sumber energi selama proses metamorfosis (Jensen et al., 2013). Komponen asam lemak tersebut salah satunya adalah DHA yang merupakan komponen penting untuk pertumbuhan dan sintasan larva. DHA berperan dalam meningkatkan aktivitas enzim dan fluiditas membrane seluler, memfasilitasi aktivitas metabolisme dan membantu proses osmoregulasi yang diperlukan dalam meningkatkan densitas larva ketika proses tansisi dari pelagis menjadi bentik (Gendron et al., 2013).

Komponen nutrisi penting lainnya adalah protein. Protein merupakan bagian integral untuk pertumbuhan, perbaikan, dan pemeliharaan sel, serta asam amino elemen penting untuk semua makhluk hidup. Protein terhidrolisis yang diformulasikan dalam pakan komersial sangat potensial dalam meningkatkan pertumbuhan larva lobster P. ornatus (Gamble et al., 2015). Sedangkan dalam penelitian ini, nilai proksimat untuk kadar protein sebagai salah satu nutrisi yang berperan dalam pertumbuhan menunjukkan bahwa pada Artemia yang baru menetas telah memiliki kadar pro tein yang cukup tinggi $(51,6 \%$, perlakuan pengayaan dengan fitoplankton Isochrysis memberikan sedikit peningkatan kadar protein Artemia $(52,55 \%$, namun pada perlakuan lain menunjukkan penurunan kadar protein setelah dilakukan inkubasi selama 18 jam. Penurunan ini diduga karena adanya pemanfaatan protein untuk metabolisme Artemia selama masa inkubasi.

\section{Pengamatan Bakteri Media Pemeliharaan}

Menurunnya sintasan pada pemeliharaan D-12 dan D-20 dapat disebabkan oleh penurunan kualitas air media pemeliharaan dengan jumlah bakteri yang meningkat pada pengamatan D-18 (Gambar 2). Peningkatan bakteri disebabkan adanya sisa Artemia yang mati dan mengendap, serta lumut yang mulai menempel di permukaan bak. Keberadaan bakteri pada media pemeliharaan dapat mengganggu, menginfeksi maupun menjadi penyebab kematian larva. Penyiponan sisa pakan sulit dilakukan karena terdapat larva yang berenang pada bagian dasar bak. Sedangkan hasil pengukuran kualitas air media ( $\mathrm{pH}$ dan salinitas) tidak ada perubahan yang signifikan (Tabel 2). 


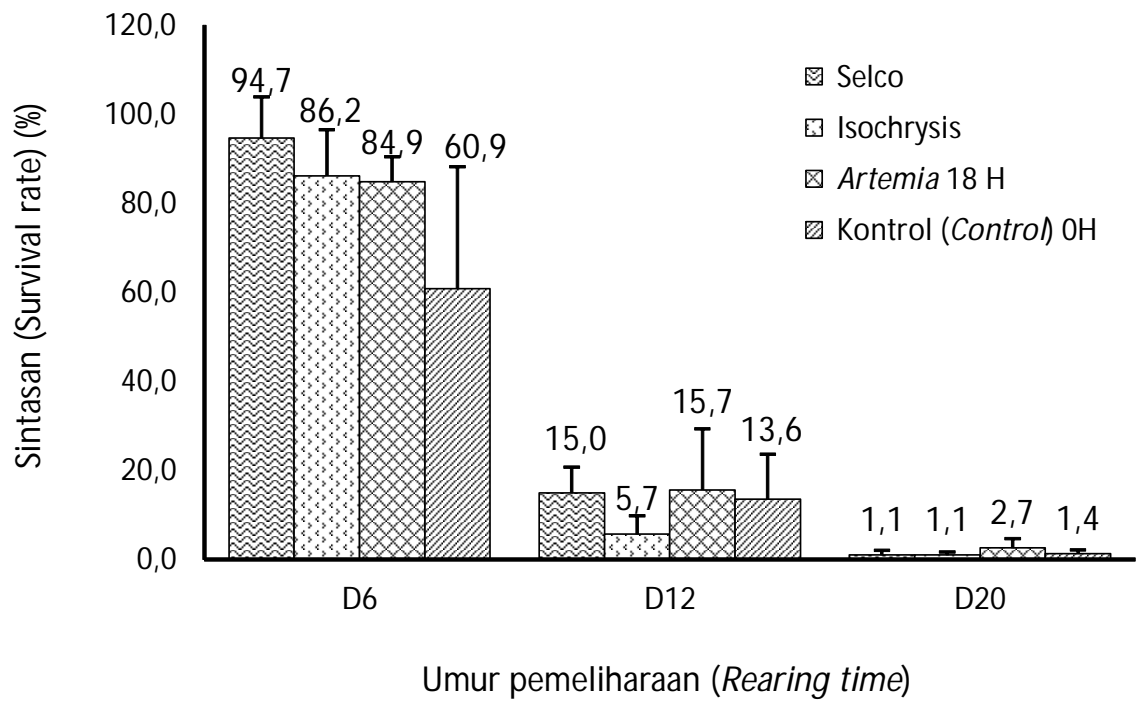

Gambar 1. Persentase sintasan larva lobster.

Figure 1. Survival rate of lobster larvae.

Tabel 1. Hasil uji proximat pakan alami Artemia

Table 1. Result of Artemia proximate analysis

\begin{tabular}{lccccc}
\hline \multirow{1}{*}{$\begin{array}{c}\text { Parameter } \\
\text { Parameters }\end{array}$} & \multicolumn{2}{c}{$\begin{array}{c}\text { Artemia tanpa pengayaan } \\
\text { Artemia without enrichment }\end{array}$} & & \multicolumn{2}{c}{$\begin{array}{c}\text { Artemia dengan pengayaan } \\
\text { Artemia with enrichment }\end{array}$} \\
\cline { 2 - 3 } & $\begin{array}{c}\text { Kontrol 0 jam setelah menetas } \\
\text { Control 0 hour after hatching }\end{array}$ & $\begin{array}{c}\mathbf{1 8} \text { jam setelah menetas } \\
\mathbf{1 8} \text { hours after hatching }\end{array}$ & & Selco & Isochyrisis \\
\hline $\begin{array}{l}\text { Kadar lemak } \\
\text { Fat content (\%) }\end{array}$ & 17,34 & 11,69 & & 21,16 & 11,92 \\
$\begin{array}{l}\text { Kadar protein } \\
\text { Protein content (\%) }\end{array}$ & 51,60 & 50,52 & & 46,43 & 52,55 \\
\hline
\end{tabular}

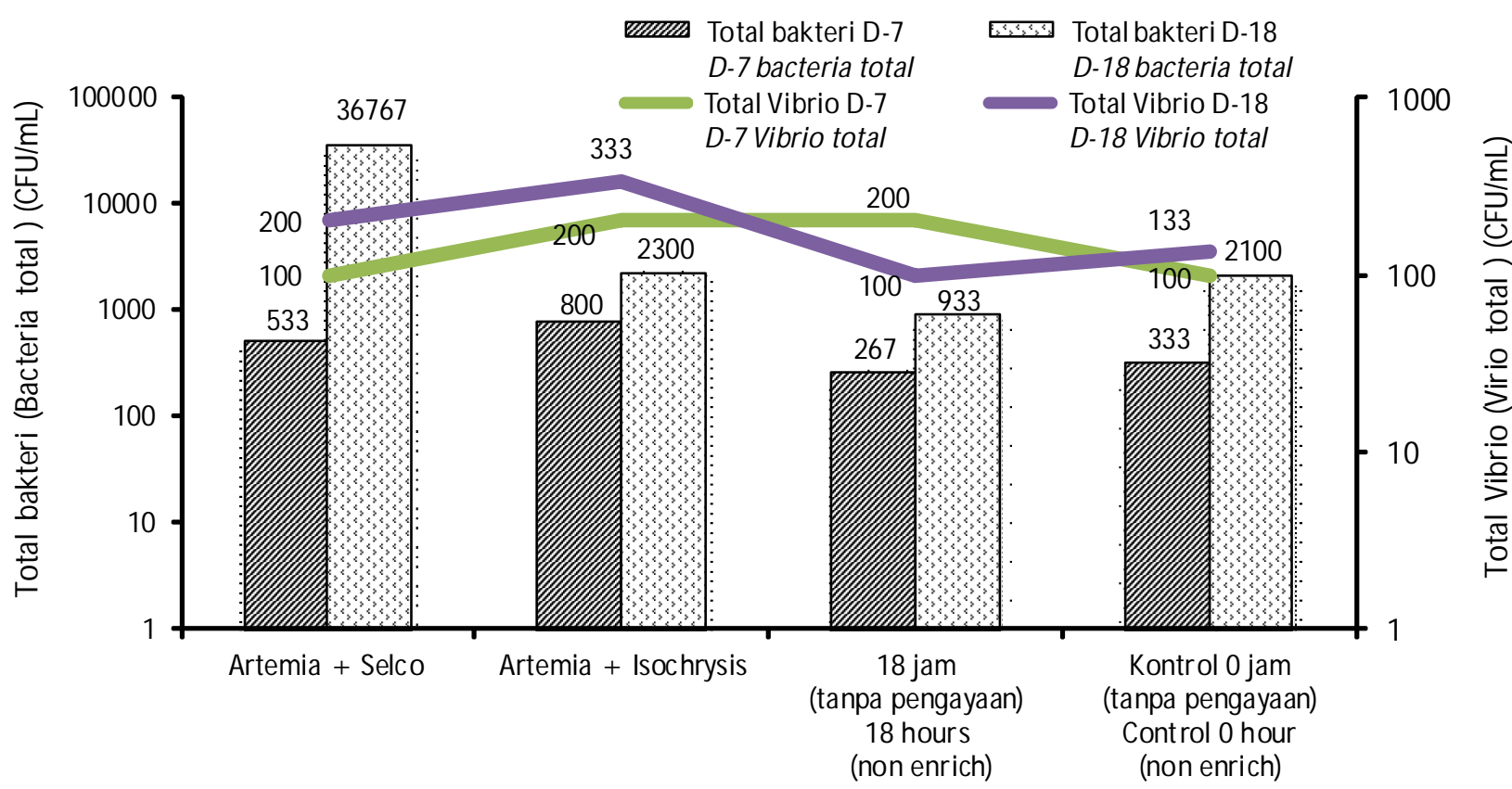

Gambar 2. Jumlah total bakteri dan total Vibrio pada media pemeliharaan larva.

Figure 2. Total number of bacteria and Vibrio during the experiment. 
Tabel 2. Kualitas air media pemeliharaan larva

Table 2. Water quality of rearing tank during the experiment

\begin{tabular}{|c|c|c|c|c|c|c|c|c|}
\hline \multirow[t]{2}{*}{$\begin{array}{c}\text { Umur } \\
\text { pemeliharaan } \\
\text { Rearing time }\end{array}$} & \multicolumn{2}{|c|}{ DHA selco } & \multicolumn{2}{|r|}{ Isochrysis } & \multicolumn{2}{|c|}{$\begin{array}{c}18 \text { jam } \\
\text { (tanpa pengayaan) } \\
18 \text { hours } \\
\text { (non-enriched) }\end{array}$} & \multicolumn{2}{|c|}{$\begin{array}{c}\text { Kontrol } 0 \text { jam } \\
\text { (tanpa pengayaan) } \\
\text { Control } 0 \text { hour } \\
\text { (non-enriched) }\end{array}$} \\
\hline & pH & $\begin{array}{c}\text { Salinitas } \\
\text { Salinity (ppt) }\end{array}$ & $\mathrm{pH}$ & $\begin{array}{c}\text { Salinitas } \\
\text { Salinity (ppt) }\end{array}$ & pH & $\begin{array}{c}\text { Salinitas } \\
\text { Salinity (ppt) }\end{array}$ & $\mathrm{pH}$ & $\begin{array}{c}\text { Salinitas } \\
\text { Salinity (ppt) }\end{array}$ \\
\hline D-11 & 8,21 & 35,3 & 8,17 & 35,6 & 8,21 & 35,0 & 8,11 & 35,6 \\
\hline D-16 & 8,19 & 35,0 & 8,16 & 35,0 & 8,20 & 35,0 & 8,20 & 35,6 \\
\hline D-19 & 8,22 & 35,0 & 8,19 & 35,0 & 8,22 & 35,0 & 8,19 & 35,0 \\
\hline
\end{tabular}

\section{Perkembangan Larva}

Larva lobster memberikan respons positif dengan pemberian Artemia sebagai pakan awal. Hal ini ditunjukkan dengan organ pencernaan berwarna oranye yang terisi penuh oleh makanan (Gambar 3a) dan kemampuan larva dalam menangkap Artemia (Gambar 3b) dengan menggunakan kaki paling belakang (periopod ke-3) yang di bagian ujungnya memiliki bentuk berduri (Gambar 3c). Larva lobster mulai makan segera setelah menetas dengan sedikit ketergantungan pada cadangan kuning telur (Ikeda et al., 2011). Larva lobster makan Artemia dengan cara menombak menggunakan terminal dactyl pada kakinya kemudian mangsa di arahkan ke mulut dengan maxilipeds. Artemia dicabik-cabik dan material cair dari tubuh Artemia disedot ke dalam usus bagian depan. Karapas Artemia seringkali dibuang setelah dikosongkan (Wang et al., 2014).
Larva yang baru menetas berwarna transparan dilengkapi empat pasang kaki (periopod) yang bertangkai seperti kipas dengan bulu (setae) yang digunakannya untuk berenang. Perkembangan larva lobster dari stadia-I ke stadia berikutnya ditandai dengan penambahan umbai-umbai dan bulu (setae), serta perubahan selubung kepala (cephalic shield) (Abrunhosa et al., 2008). Pada larva stadia-I ini organ yang digunakan untuk berenang terdapat pada periopod 1-2 dengan jumlah setae sebanyak lima pasang. Sedangkan pada periopod ke-3 belum berkembang (Gambar 4a). Hal paling mudah untuk membedakan setiap stadia larva diketahui dari jumlah setae yang bertambah. Pada penelitian ini, karena larva hanya mampu bertahan pada umur 20 hari (hanya mampu mencapai larva stadia-IIla) dengan setae berjumlah tujuh pasang (Gambar 4c). Pada semua perlakuan mampu mencapai stadia-Illa pada 20 hari pemeliharaan.
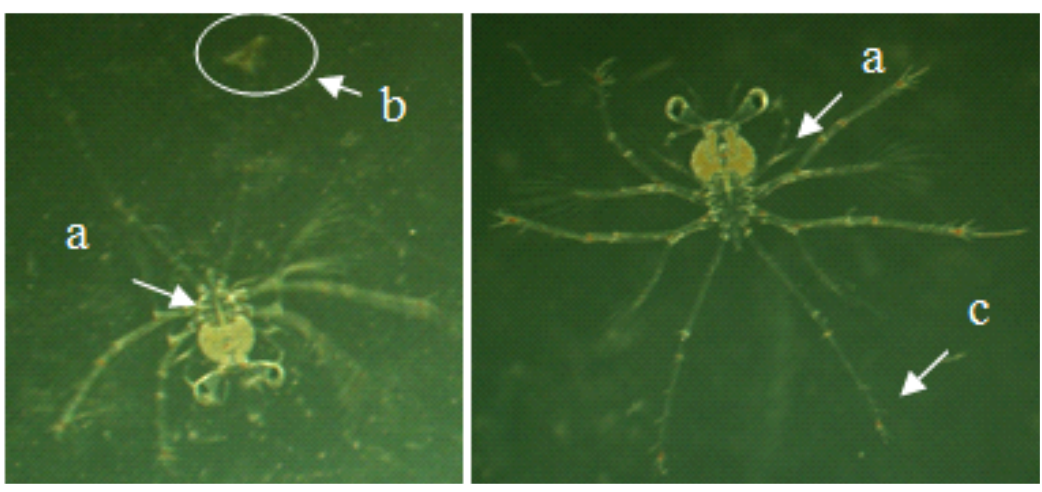

Gambar 3. Larva lobster P. homarus dengan organ pencernaan penuh makanan berwarna oranye (a); larva membawa Artemia (b); larva memiliki periopod yang berduri untuk menangkap Artemia (c).

Figure 3. Lobster larvae of $\mathbf{P}$. homarus with fully digestive organs indicated by orange colour (a); larvae eating Artemia (b); larvae with spine in periopod to catch artemia (c). 
Selain jumlah setae yang berbeda pada setiap stadia, perkembangan larva juga dapat dilihat dengan jelas dari jumlah setae pada periopod ketiga. Pada larva stadia-1 dan 2, setae pada periopod ketiga belum berkembang. Pada stadia-II setae tersebut masih dan berbentuk seperti duri yang sedikit memanjang. Sedangkan pada larva stadia-III, setae pada periopod ketiga telah berjumlah tiga pasang (Gambar 5). Pada perkembangan tangkai mata stadia-l berbentuk sedikit membulat dan belum bersegmen. Sedangkan pada stadia-II dan III tangkai mata telah bersegmen dan terlihat adanya ruas membentuk tangkai. Pada selubung kepala berbentuk bulat pada larva stadia-I dan menjadi lonjong pada stadia berikutnya (Gambar 6).
Artemia terbukti mampu diterima sebagai pakan awal larva lobster. Pemberian pakan Artemia saja telah mampu mencukupi kebutuhan larva lobster mencapai perkembangan stadia-IIla dengan morfologi sesuai Abrunhosa et al. (2008). Pemberian bahan pengaya pada Artemia sebagai pakan utamalobster memberikan hasil yang tidak berbeda nyata pada sintasan larva (P value $>0,05)$. Pada pemeliharaan enam hari pertama, pengayaan dengan selco menunjukkan sintasan yang lebih tinggi ( $\mathrm{SR}=94,6 \%$ ) dibandingkan dengan perlakuan lain. Hal ini didukung dengan hasil analisis proksimat pengayaan dengan selco memiliki nilai kadar lemak yang paling tinggi yaitu $21,16 \%$ DHA selco mampu memperkaya Artemia setelah 24 jam
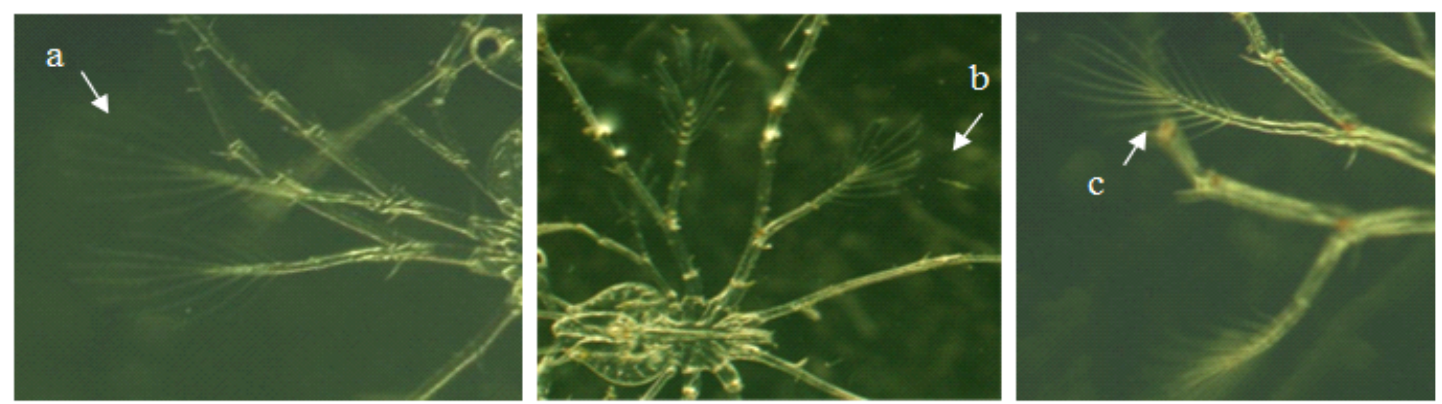

Gambar 4. Jumlah setae stadia-I : lima pasang (a), II : enam pasang (b), Illa : tujuh pasang (c). Figure 4. Setae number in stage-I : five pairs (a), II : six pairs (b), IIla : seven pairs (c).
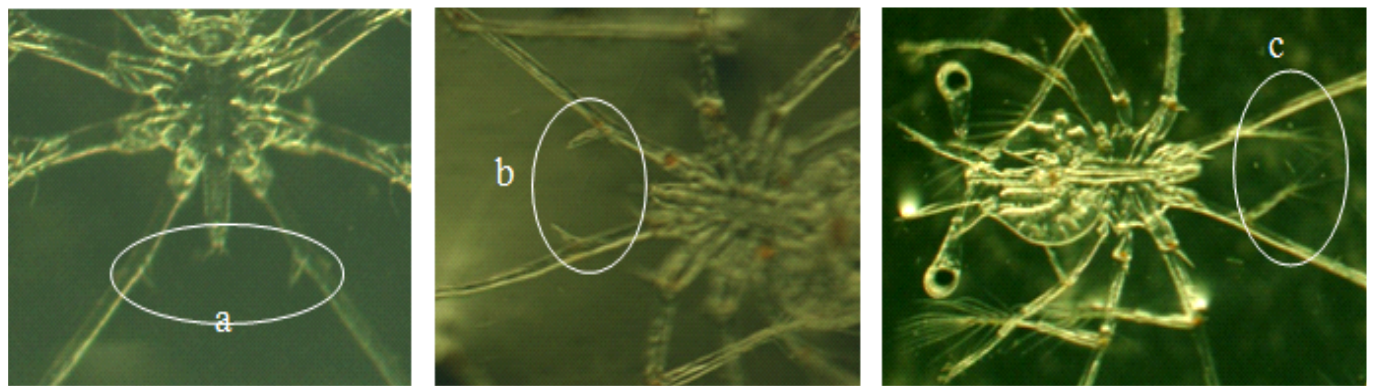

Gambar 5. Bentuk periopod ke-4 pada stadia-I (a), stadia-II (b), stadia-IIla (c).

Figure 5. Shape of periopod 4 in stage-I (a), stage-II (b), stage-IIla (c).
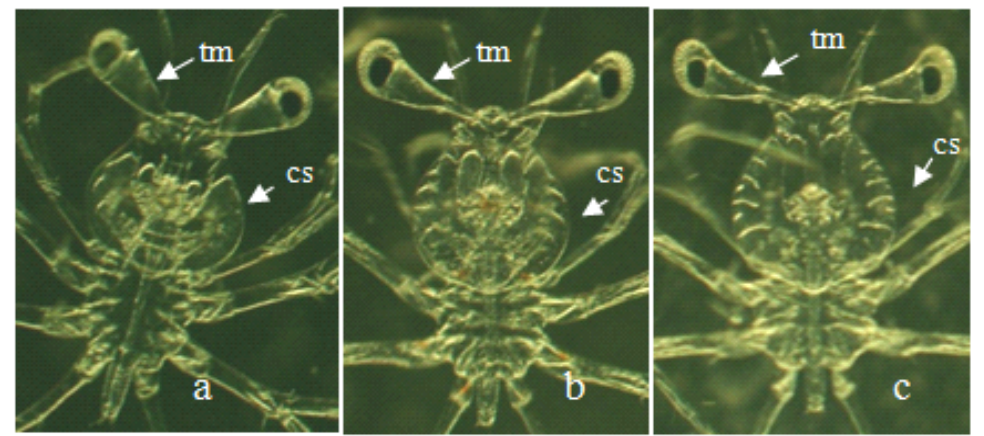

Gambar 6. Bentuk selubung kepala cs dan tangkai mata: tm pada larva stadia-I (a), stadiaII (b), stadia-IIla (c).

Figure 6. Cephalic shield: cs dan eyes stalk: tm in stage-I (a), stage-II (b), stage-IIla (c). 
pengayaan dengan nilai konsentrasi DHA 15,4\% dibandingkan dengan pengayaan menggunakan alga yang hanya $0,2 \%$ (Phleger et al., 2001).

Nilai sintasan tertinggi pada akhir penelitian dicapai pada Artemia yang diinkubasi selama 18 jam tanpa diberikan bahan pengaya. Hal ini diduga karena pada perlakuan pemberian bahan pengaya dan Artemia yang baru menetas memiliki nilai nutrisi yang lebih tinggi dibandingkan dengan perlakuan kontrol 18 jam (Tabel 1), sehingga menjadi sarana media yang baik bagi pertumbuhan bakteri yang ditunjukkan dengan nilai total bakteri dan total Vibrio yang relatif lebih tinggi. Pemberian nauplii Artemia yang diperkaya dapat bertindak sebagai vektor bagi masuknya bakteri patogen (Haché \& Plante, 2011). Beberapa strain bakteri yang diisolasi dari produksi nauplii Artemia antara lain dari genus Vibrio, Pseudomonas, Micrococcus, Brevundimonas, Spingomonas, dan Rhizobium (Hoj et al., 2009).

Kegiatan pembenihan lobster di berbagai negara masih terus dikembangkan sampai saat ini. Sintasan yang rendah menjadi kendala utama keberhasilan pembenihan. Pada kegiatan pembenihan Iarva Carribean lobster (Panulirus argus) di Florida diperoleh nilai SR 47\%pada D-30, 36\%pada D-60, 28\% pada D100 , dan 23\%pada D-150. Total terdapat 13 larva yang berhasil bermetamorfosis menjadi BBL pada 151-311 hari pemeliharaan (Goldstein et al., 2008). Hasil penelitian mereka lebih baik dari penelitian ini diduga karena tingkat kepadatan yang lebih rendah yaitu menggunakan bak berukuran $40 \mathrm{~L}$ dengan jumlah larva 550 ekor/bak. Selain itu, tindakan preventif akan introduksi penyakit juga dilakukan dengan menggunakan sistem air membrane filtrasi $0,2 \mathrm{~m}$ dengan pemberian antibiotik chloramphenicol $10 \mathrm{mg} /$ L selama 24 jam setiap minggu (Goldstein et al., 2008).

Pada penelitian ini dalam masa pemeliharaan banyak ditemukan larva yang berkerumun di dasar bak terutama pada siang hari. Hal diduga menjadi penyebab banyaknya kematian larva pada keesokan harinya. Sebagian besar larva pada stadia-II dan seterusnya cenderung berada di bagian bawah bak pemeliharaan dan kebanyakan ikut terbawa saat penyiponan dasar bak untuk mengurangi kotoran dan larva yang mati (Vijayakumaran et al., 2014). Stres pada saat penanganan, berkerumunnya larva, dan tingginya jumlah Vibrio pada perkembangan stadia menjadi beberapa penyebab kematian (Vijayakumaran et al., 2014).

Agen utama penyakit pada larva cukup umum ditemui seperti pada budidaya lainnya, meliputi virus, bakteri, jamur, protozoadan metazoa (Shield, 2011). Organisme ini ditemukan banyak terdapat pada air laut. Oleh karenanya perlu perhatian khusus pada kualitas air laut yang masuk utamanya pada tempat penetasan karena ini dapat menyebabkan kematian yang signifikan melalui induksi tertentu yang menyebabkan larva stres, penurunan aktivitas, perubahan warna, perilaku makan yang terganggu, perubahan bentuk tubuh, dan pernapasan. Apabila tanda-tanda klinis tersebut telah teramati maka mungkin sudah terlambat untuk melakukan tindakan dalam mengurangi kematian massal (Hall et al., 2013).

Pada penelitian ini penyebab lain yang diduga menjadi penghambat dalam pemeliharaan larva lobster adalah mudahnya bagian tubuh Artemia menjadi kotor (Gambar 7a) akibat adanya penempelan oleh protozoa. Penempelan kotoran biasa pada tubuh larva lobster sebenarnya mampu dibersihkan oleh maxilliped ketiga maupun kaki pertama hingga kelima (Kamio et al., 2015). Namun penempelan protozoa pada kaki-kaki tersebut sulit dibersihkan dan mengganggu pergerakan, serta aktivitas larva untuk menangkap mangsa. Larva yang tubuhnya kotor dan berenang lesu merupakan ciri larva yang tidak sehat (Matsuda et al., 2012). Pada akhirnya akan menjadi salah satu penyebab kematian. Beberapa jenis protozoa yang ditemukan menyerang larva pada masa pemeliharaan diduga adalah dari jenis Zoothamnium sp. (Gambar 7b), dan filamentous bacterium (Gambar 7c). Vijayakumaran et al. (2014) menyebutkan bahwa protozoa yang umum ditemukan adalah jenis Zoothamnium sp., filamentous bacterium, dan Leucotrix sp.; sementara Acinata sp., Ephistylis sp., dan vorticella tercatat sesekali menyerang larva.

Pada penelitian pendahuluan juga ditemukan protozoa jenis Zoothamnium sp. maupun filamentous bacterium pada larva lobster bahkan pada telur. Infeksi jamur pada telur juga dilaporkan terjadi pada lobster mutiara yang mengakibatkan perubahan warna telur (Yap et al., 2020). Infeksi jamur menjadi penyebab utama kegagalan dan kematian massal dalam produksi benih krustasea (Hatai, 2012). Selain itu, jenis siliata yang juga sering teramati menempel pada lobster dewasa maupun embrio telur yang berasal dari Genus Vorticella dan Zoothamnium, Acineta, Ephelota, Cyanobacteria, dan diatom. Dampak akibat penempelan ini berakibat pada kematian larva akibat gangguan respirasi (Shields et al., 2006). Tindakan preventif dalam mencegah munculnya parasit ini harus dilakukan sejak pemeliharaan induk maupun sebelum penebaran larva. Perendaman selama 10 menit dengan malachite green $(10 \mathrm{mg} / \mathrm{L})$, formalin $(25 \mathrm{mg} / \mathrm{L})$, streptomycin (0,5-1 $\mathrm{mg} / \mathrm{L})$ dapat digunakan sebagai treatment untuk mendesinfeksi induk dan larva dari jenis protozoa tersebut (Vijayakumaran et al., 2014). Namun, penggunaan beberapa desinfektan tersebut 


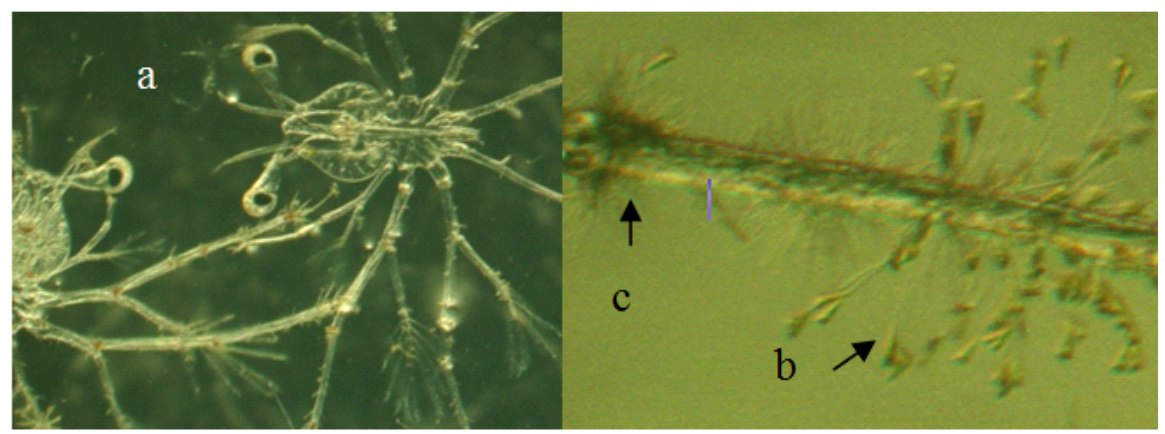

Gambar 7. Penempelan pada bagian tubuh larva lobster; tubuh larva yang kotor (a), Zoothamnium sp. (b), filamentous bacterium (c).

Figure 7. Microorganisme attaching to the body part of larvae (a), Zoothamnium sp. (b), filamentous bacterium (c).

tidak disarankan untuk kegiatan budidaya terutama pada penggunaan antibiotik streptomycin bahkan malachite green termasuk salah satu jenis obat ikan dan udang yang dilarang dalam Permen KP No.39 tahun 2015. Oleh sebab itu, dalam penelitian ini digunakan iodine yang merupakan desinfektan yang tidak tercantum pada peraturan tersebut.

Keberhasilan pembenihan larva lobster sangat ditentukan oleh kesesuaian jenis pakan yang mampu ditangkap oleh larva lobster dan kandungan nutrisi yang diperlukannya. Sedangkan kualitas media pemeliharaan yang baik dengan bebas dari bakteri dan protozoa menjadi salah satu kunci pertumbuhan dan sintasan larva. Francis et al. (2014) menyebutkan keberhasilan pemenuhan kebutuhan nutrisi dari larva lobster terkait erat dengan beberapa aspek khusus dari persyaratan biologis larva. Khususnya, untuk pertumbuhan dan sintasan yang maksimal. Keseimbangan yang baik antara nutrisi dan kualitas air harus dijaga termasuk kontrol mikrobiologi dan hidrodinamik. Fluktuasi dan sub optimal kualitas air dapat menyebabkan eksoskeleton menjadi kotor sehingga berpengaruh pada pergerakan dan kemampuan menangkap makananan secara efektif.

Pengaruh lain dari fluktuasi kualitas air termasuk deformity (kecacatan) pada saat moulting (berganti kulit). Larva membutuhkan kebebasan dalam kolom air sehingga dapat secara maksimal menangkap makanan, sementara itu perlu menjaga kontak minimal antar individu agar tidak saling terpaut di dalam bak pemeliharaan (Francis et al., 2014).

Kualitas air pemeliharaan yang baik dan nutrisi, serta jenis pakan yang tepat menjadi faktor yang penting bagi perkembangan larva lobster untuk mampu melewati fase larva yang panjang hingga berubah menjadi BBL.

\section{KESIMPULAN}

Perkembangan larva lobster yang mampu dicapai pada penelitian ini adalah perkembangan stadia IIIa dengan waktu pemeliharaan larva 20 hari pada semua perlakuan. Pengayaan artemia dengan DHA selco memberikan hasil sintasan tertinggi dibandingkan perlakuan lain pada enam hari pertama pemeliharaan larva. Pemberian pakan artemia yang diperkaya dengan DHA selco akan menjadi lebih efektif bila kualitas air dikontrol dengan baik selama pemeliharaan.

\section{UCAPAN TERIMA KASIH}

Penulis sangat berterima kasih pada Ir. Sari Budi Moria Sembiring, M.Biotech., Sudewi M.Si., dan staf laboratorium kimia Balai Besar Riset Perikanan Budidaya Laut dan Penyuluhan Perikanan Gondol, Bali atas dukungan dan bantuannya dalam penelitian ini.

\section{DAFTAR ACUAN}

Abrunhosa, F.A., Santiago, A.P., \& Abrunhosa, J.P. (2008). The early phyllosoma stages of spiny lobster Panulirus echinatus Smith, 1869 (Decapoda: Palinuridae) reared in the laboratory/Os primeiros estagios de filosoma da lagosta Panulirus echinatus (Decapoda: Palinuridae) cultivados em laboratorio. Brazilian Journal of Biology, 68,(1), 187-195.

Elvantra. (2021). Harga terbaru lobster air laut dan tawar hari ini lokal dan ekspor. Maret 2021. Diakses pada 7 Juni 2021, dari: https:// elvantra.blogspot.com/2020/01/harga-lobster.html.

Conland, J.A., Jones, P.L., Turchini, G.M., Hall, M.R., $\&$ Francis, D.S. (2014). Changes in the nutritional composition of captive early-mid stage Panulirus ornatus phyllosoma over ecdysis and larval development. Aquaculture, 434, 159-170. 
Fitzgibbon, Q.P., Jeffs, A.G., \& Battaglene, S.C. (2014). The Achilles heel for spiny lobsters: the energetics of the non-feeding post-larval stage. Fish Fish, $15,312-326$.

Francis, D.S., Salmon, M.L. Kenway, M.J., \& Hall, M.R. (2014). Palinurid lobster aquaculture: Nutritional progress and considerations for successful larval rearing. Reviews in Aquaculture, 6, 180-203.

Gamble, S., Pirozzi, I., Hall, M.R., Zeng, C., Conlan, J.A., \& Francis, D.S. (2015). The effect of pre-digested protein source on the performance of early - mid stage Panulirus ornatus phyllosoma. Aquaculture, 440, 17-24.

Gendron, L., Tremblay, R., Belvin, S., Génard, B., Motnikar, S., \& Côté, J. (2013). Condition, survival and growth in situ of hatchery-reared stage IV lobster (Homarus americanus) fed Artemia and lipid-rich wild zooplankton. Aquaculture, 416-417, 380-389.

Goldstein, J.S., Matsuda, H., Takenouchi, T., \& Butler, M.J. (2008). The complete development of larval caribbean spiny lobster Panulirus argus (Latreille, 1804 ) in culture. Journal of Crustacean Biology, 28(02), 306-327.

Grima, E.M.,. Pérez, J.A.S., Sánchez, J.L.G., Camachoa, F.G., \& Alonso, D.L. (1992). EPA from Isochrysis galbana. Growth conditions and productivity. Process Biochemistry, 27, 299-305.

Haché, R. \& Plante, S. (2011). The relationship between enrichment, fatty acid profiles and bacterial load in cultured rotifers (Brachionus plicatilis L-strain) and Artemia (Artemia salina strain Franciscana). Aquaculture, 311, 201-208.

Hall, M.R., Kenway, M., Salmon, M., Francis, D., Goulden, E.F., \& Høj, L. (2013). Palinurid lobster larval rearing for closed-cycle hatchery production. Australian Institute of Marine Science (AIMS), Australia. Woodhead Publishing Limited, 2013. DOI: 10.1533/9780857097460.2.289.

Hatai, K. (2012). Diseases of fish and shellfish caused by marine fungi. In Raghukumar, C. (Ed.). Biology of Marine Fungi. Springer, p. 15-52.

Høj, L., Bourne, D.G., \& Hall, M.R. (2009). Localisation, abundanceand community structure of bacteria associated with Artemia: effects of nauplii enrichment and antimicrobial treatment.Aquaculture 293: 278-285 Growth Conditions and Productivity. Process Biochemistry, 27, 299-305.

Ikeda, T., Smith, G., McKinnon, A.D., \& Hall, M. (2011). Metabolism and chemical composition of phyllosoma larvae, with special reference to the tropical rock lobster Panulirus ornatus (Decapoda; Palinuridae). Journal of Experimental Marine Biology and Ecology, 405, 80-86.

Jensen, M.A., Carter, C.G., Adams, L.R., \& Fitzgibbon, Q.P. (2013). Growth and biochemistry of the spiny lobster Sagmariasus verreauxi cultured at low and high density from hatch to puerulus. Aquaculture, 376-379, 162-170.

Junaidi, M., Cokrowati, N., \& Abidin, Z. (2011). Tingkah laku induk betina selama proses pengeraman telur dan perkembangan larva lobster pasir (Panulirus homarus, Linneaus, 1785). Jurnal Akuatika, 2(1), 1-10.

Kamio, M., Furukawa, D., Wakabayashi, K., Hiei, K., Yano, H., Sato, H., Yosie-Stark, Y, Akiba, T., \& Tanaka, Y. (2015). Grooming behavior by elongated third maxillipeds of phyllosoma larvae of the smooth fan lobster riding on jellyfishes. Journal of Experimental Marine Biology and Ecology, 463, 115-124.

Matsuda, H., Takenouchi, T., Tanaka, S., \& Watanabe, S. (2009). Relative contribution of Artemia and mussel as food for cultured middle-stage Panulirus japonicus phyllosomata as determined by stable nitrogen isotope analysis. New Zealand Journal of Marine and Freshwater Research, 43, 217-224.

Matsuda, H., Abe, F., \& Tanaka, S. (2012). Effect of photoperiod on metamorphosis from phyllosoma larvae to puerulus postlarvae in the Japanese spiny lobster Panulirus japonicus. Aquaculture, 326-329, 136-140.

Mustafa, A. (2013). Budidaya lobster Panulirus sp. di Vietnam dan aplikasinya di Indonesia. Media Akuakultur, 8(2), 73-84.

Phleger, C.F., Nelson, M.M., Nichols, P.D., Ritar, A.J., Smith, G.G., Hart, P.R., \& Jeffs, A.G. (2001). Lipids and nutrition of the southern rock lobster, Jasus edwardsii from hatch to puerulus. Marine and Freshwater Research, 52, 1475-1486.

Priyambodo, B. (2015). Study tour of Indonesian farmers to Vietnam lobster aquaculture industry in 2013. Chapter 5.8. In Jones, C.M. (Ed.). Spiny lobster aquaculture development in Indonesia, Vietnam and Australia. Proceedings of the International Lobster Aquaculture Symposium Held in Lombok, Indonesia, 22-25 April 2014. Australian Centre for International Agricultural Research, Canberra, Australia, p. 136-141.

Priyambodo, B., Jones, C.M., \& Sammut, J. (2020). Assessment of the lobster puerulus (Panulirus homarus and Panulirus ornatus, Decapoda: 
Palinuridae) resource of Indonesia and its potential for sustainable harvest for aquaculture. Aquaculture, 528, 735563.

Prusinska, M., Nowasad, J., Jarmo³owicz, S., Mikiewicz, M., Duda, A., Wiszniewski, G., Sikora, M., ....., \& Kucharczyk, D. (2020). Effect of feeding barbel larvae (Barbus barbus (L, 1758)) Artemia sp. nauplii enriched with PUFAs on their growth and survival rate, blood composition, alimentary tract histological structure and body chemical composition. Aquaculture Reports, 18, 100492. https:/ /doi.org/10.1016/j.aqrep.2020.100492.

Shields, J.D., Stephens, F.J., \& Jones, B. (2006). Pathogens, parasites and other symbionts. Lobster: Biology, management, aquaculture and fisheries. Blackwell Publishing Ltd. Chapter 5, 146-204.

Shields, J.D. (2011). Diseases of spiny lobsters: A review'. J. Invertr. Pathol., 106, 79-91.

Vijayakumaran, M., Maharajan, A., Rajalakshmi, S., Jayagopal, P., \& Remani, M.C. (2014). Early larval stages of the spiny lobsters, Panulirus homarus, Panulirus versicolor and Panulirus ornatus cultured under laboratory conditions. International Journal of Development Research, 4(2), 377-383.

Wang, M., O'Rorke, R., Nodder, S.D., \& Jeffs, A.G. (2014). Nutritional composition of potential zooplankton prey of the spiny lobster phyllosoma (Jasus edwardsii). Mar. Freshw. Res., 64, 1-13.

Wang, M., Mackenzie, A.D., \& Jeffs, A.G. (2015). Lipid and fatty acid composition of likely zooplankton prey of spiny lobster (Jasus ed wardsii) phylosomas. Aquaculture Nutritition, 21, 385-400.

Wu, X., Smith, G., \& Hall, M. (2011). Patterns of larval growth, lipid composition and fatty acid deposition during early to mid stages of development in Panulirus ornatus phyllosoma. Aquaculture, 330333, 63-73.

Yap, S.Y., Hamasaki, K., Maran, B.A.V., Tuzan, A.D., Ch'ng, C.L., \& Lal, T.M. (2020). First report of plant fungal pathogen Zasmidium musae associated with moribund eggs of ornate spiny lobster (Panulirus ornatus) in Sabah. Aquaculture Reports, $18,100500$. 